STUDIA UKRAINICA POSNANIENSIA, vol. II: 2014, pp. 283-292.

ISBN 978-83-936654-5-7. ISSN 2300-4754.

\title{
ІНТЕРТЕКСТУАЛЬНІСТЬ ДРАМИ СПИРИДОНА ЧЕРКАСЕНКА ЦІНА КРОВІ
}

\author{
ОКСАНА КУЗЬМА \\ Ужгородський національний університет, Ужгород - Україна \\ INTERTEKSTUALNOŚĆ DRAMATU \\ SPYRYDONA CZERKASENKI CENA KRWI \\ OKSANA KUŹMA \\ Użhorodzki Narodowy Uniwersytet, Użhorod - Ukraina
}

STRESZCZENIE. W artykule poddano analizie intertekstualność dramatu Cena krwi S. Czerkasenki, ukraińskiego pisarza-modernisty. Śledzi się pionierstwo artysty w interpretacji ewangelicznej fabuły o Judaszu. W dramacie okazuje się kulturalne wpływy, asocjacje, ślady „cudzych tekstów", a także właściwości odautorskiego rozumienia zdrady.

\section{INTERTEXTUALITY OF DRAMA \\ OF SPYRYDON CHERKASENKO BLOOD PRICE}

\author{
OKSANA KUZMA \\ Uzhgorod National University, Uzhgorod - Ukraine
}

ABSTRACT. This article deals with the analysis of the intertextuality of the drama Blood Price by S. Cherkasenko, a Ukrainian modernist writer. The artist's innovation in understanding the Gospel story about Judas Iscariot is traced. In the drama there are revealed cultural influences, associations, traces of "other texts", the features of the author's understanding of the phenomenon of betrayal is examined.

\footnotetext{
пиридон Черкасенко (1876-1940) - український письменник-модерніст, творчість якого довгий час залишалася за межами наукової рецепції вчених-літературознавців. Це самобутній лірик, цікавий прозаїк, драматург-новатор, який творив у руслі художніх пошуків митців доби модернізму. С. Черкасенко відомий і як публіцист, працівник театральної сфери, талановитий педагог, автор численних праць освітянського спрямування (читанок, букварів, граматик). Це була особистість діяльного характеру, яка невтомно і подвижницьки працювала на ниві рідної культури.

Творчий доробок С. Черкасенка різноманітний за тематикою, родо-жанровими формами, стильовими особливостями. Самобутністю, оригінальним трактуванням проблем загальнолюдського та національного звучання вирізняється драматургія автора. Такі твори письменника, як Хуртовина (1907), Повинен (1908), Казка старого млина (1913), Про щзо тирса шелестіла (1916),
} 
Ціна крові (1930) є надбанням національного драматичного мистецтва. Вони засвідчили новаторство митця в розбудові української драматургії початку ХХ століття.

Окреме місце в доробку С. Черкасенка займає твір Ціна крові, зразок національної християнсько-релігійної драматургії (С. Хороб). Письменник звернувся до відомого євангельського сюжету про зраду Юди Іскаріота, розробкою якого займалися різні письменники. А. Нямцу цілком слушно наголосив, що „характер використання традиційного символічного навантаження євангельського персонажа і діапазон його трансформації світовою літературою та культурою в цілому надзвичайно багатоманітні і суперечливі" . Найвідоміші інтерпретації зради Юди у світовій літературі - це насамперед твори Г. Панаса (Свангеліє від Юди), Г. Гауптмана (Юда), Г. Даниловського (Марія Магдалина), Х.Л. Борхеса (Три версї зради Юди), Л. Андреєва (Юда Iскаріот), С. Пшибишевського (На иляхах Кайна), С. Ердега (Безіменна могила), Ж. Сарамаго (Євангеліє від Iсуса) та ін. В українському письменстві образ Юди цікаво трактується в драмі Лесі Українки На полі крові, в поезіях О. Романової Юда й А. Кримського Іуда Скаріотський, у прозових творах О. Кобилянської (Юда), В. Петрова (Апостоли), В. Дрозда (Іскаріот) тощо.

Ціна крові С. Черкасенка - одна із оригінальних версій євангельського сюжету про зрадника Месії, цінна, за словами О. Мишанича, „фактом освоєння українським письменством світових тем і образів" ${ }^{2}$. Учені розглядали драму автора у різних аспектах. Грунтовні оцінки твору містяться в дослідженні В. Антофійчука та А. Нямцу Євангельські мотиви в украйнській літературі кіния $X I X-X X \mathrm{~cm}^{3}{ }^{3}$, в окремих працях М. Кудрявцева, С. Хороба. Принагідно до аналізу Ціни крові звертався О. Мишанич, який $\epsilon$ автором статті-передмови до двотомного видання творів С. Черкасенка.

У сучасному українському літературознавстві популярними $є$ компаративістичні студії, які дозволяють простежити культурно-літературний контекст окремих творів письменників, їх функціонування у системі інших дискурсивних практик. Теорія інтертекстуальності дає широкі інтерпретаційні можливості для науковців. Вважаємо, що Ціна крові С. Черкасенка $є$ вдячним матеріалом для інтертекстуального аналізу. Окремі аспекти, цікаві для такої методики вивчення художнього твору, наголошувалися в працях вище згаданих дослідників. Так, В. Антофійчук та А. Нямцу слушно зауважують: „Привертає увагу явна подібність концепції героя драми С. Черкасенка 3 теоретичною побудовою повісті Вол. Соловйова Антихрист і знаменитої Легенди про Великого

${ }^{1}$ А. Н я м ц у, Предательство Иуды (философско-психологические трактовки и литературные версии евангельской колизии), [в:] „Біблія і культура” 2000, вип. 2, с. 84.

${ }^{2} \mathrm{O}$. М и ш а н и ч, В безмежжі зим і чужини... (Повернення Спиридона Черкасенка), [в:] С. Ч е р к а с е н к о, Твори: в 2 m., т. 1, Київ 1991, с. 29.

${ }^{3}$ В. А н т о ф і й ч у к, А. Н я м ц у, Свангельські мотиви в украйнській літературі кіния XIX-XX ст., Чернівці 1996, 208 с. 
інквізитора в романі Ф.М. Достоєвського Брати Карамазови”“4. У монографії дослідників паралелі з названими творами ледь окреслені, вони потребують ширшої інтерпретації, зокрема типологічного зіставлення Ціни крові з творами Ф. Достоєвського.

С. Хороб відносить драму С. Черкасенка до зразків української релігійно-християнської драми. За словами ученого, „авторська художня свідомість тут вибудовує постать Іуди через його сприйняття натовпу зі своїми слабкостями й фанатизмом, через його використання деякої обмеженості учнів Месії, нарешті, через його підступність і хитрощі"

Погоджуємося з ученими, які акцентують на зв'язкові творчості С. Черкасенка 3 художнім доробком Лесі Українки. Л. Дем'янівська, зокрема, твердить, що драматичні поеми автора, насамперед Казка старого млина, фактично виростають, постають 3 драми-феєрії Лісова пісня ${ }^{6}$. Гадаємо, що тут можна говорити і про смисловий, жанровий, поетикальний зв'язок драм Ціна крові С. Черкасенка та На полі крові Лесі Українки. У свій час дослідник творчості Лесі Українки О. Бабишкін вважав, що Ціна крові С. Черкасенка є своєрідним запереченням драми На полі крові, адже, як твердив учений, у п'єсі, як і в твоpax Л. Андреєва, П. Гейзе, Т. Гедберга, реабілітується поняття зради ${ }^{7}$. Позиція О. Бабишкіна була зумовлена впливом вульгарного соціологізму, який „панував” у критичних оцінках радянських літературознавців. Тому вважаємо драму С. Черкасенка не запереченням твору Лесі Українки, а поглибленням, доповненням мотивацій Юдиної зради.

Звичайно, критична рецепція драми Ціна крові не вичерпується названими дослідженнями. Але спостереження вчених слугують своєрідними точками відштовхування для інтертекстуального аналізу твору С. Черкасенка.

Обгрунтування теорії інтертекстуальності пов'язане передусім з іменами М. Бахтіна, Ю. Крістевої, Р. Барта. Як відзначає Л. Біловус,

праці М. Бахтіна актуалізували інтерес до поетики „чужого слова” в різних його виявах. Один із важливих висновків дослідника - діалогічність „чужого слова” і всього тексту - дозволяє думати і про принципи „поведінки” одного тексту в іншому $[\ldots]^{8}$.

Ідею „діалогізму творчого процесу” М. Бахтін розвинув у працях Проблемы творчества Достоевского, Эстетика словесного творчества та ін. На думку вченого,

\footnotetext{
${ }^{4}$ Там само, с. 66.

${ }^{5}$ С. Х о р о б, Українська релігійно-християнська драма кіния XIX-початку XX століття, [в:] О.Д. Г н і д а н (ред.), Історія украӥнської літератури. Кінець XIX - початок ХХ ст.: у 2 кн., кн. 2, Київ 2006, с. 475.

${ }^{6}$ Л. Д е м'я н і в с ь к а, Спиридон Черкасенко (1876-1940), [в:] О.Д. Г н і д а н (ред.), Історія української літератури..., зазнач. праця, кн. 2, с. 452.

${ }^{7}$ О. Б а б и ш к і н, На полі крові, [в:] Л. У к р а ї н к а, Публікаиії. Статті. Дослідження, Київ 1960, с. 157.

${ }^{8}$ Л. Б і л о в у с, Інтертекстуальність у мистецьких світах, [в:] Р. Г р о м'я к (ред.), Неймовірно важливі світи: референтність, фікиійність, текстуалізаиія, Тернопіль 2005,
} c. 214. 
чужа культура тільки в межах іншої культури розкриває себе повніше і глибше [...]. Один смисл розкриває свої глибини, зустрівшись 3 іншим, чужим смислом: між ними починається діалог, який долає замкнутість і однобічність цих смислів, цих культур. Ми ставимо чужій культурі нові запитання, які вона сама собі не ставила, ми шукаємо у ній відповіді на ці наші запитання, і чужа культура відповідає нам, відкриваючи перед нами свої нові грані [...]. При такій діалогічній зустрічі двох культур вони не зливаються і не змішуються, кожна зберігає свою єдність і відкриту цілісність, але вони взаємно збагачуються 9 .

Концепції Ю. Крістевої, Р. Барта, Ж. Женетта розширюють парадигму понять інтертекстуальності. Названі дослідники вводять у науковий обіг цілий ряд термінів на позначення проблем міжтекстової взаємодії (приміром, сам термін „інтертекстуальність”, а також поняття „мозаїка цитат” ввела Ю. Крістева, „палімпсест” - Ж. Женетт).

Ціна крові - драма, написана на основі євангельського сюжету про зрадника Юду. Тому першоджерело твору - Біблія, власне Новий Заповіт - це перше „коло” інтертекстуальності. Творчий діалог драми і канонічної біблійної версії носить характер діалогу-відштовхування. С. Черкасенко йде шляхом канонічної версії у зображенні Месії та його найближчого оточення, витримуючи оповідь у хронологічній послідовності: проповіді Ісуса, тріумфальний в'їзд до Єрусалима, розп'яття. Але все, що стосується історії Юди, набуває нових акцентів. Письменник вибудовує цілий комплекс мотивацій Юдиної зради, що різниться від канонічного трактування (пор.: в Свангелії вчинок Юди пояснюється одержимістю сатаною, бажанням збагачення, „сріблолюбством"). У драмі Ціна крові Юда прагне здобути визволення для рідного народу. Він брав участь у боротьбі за волю під керівництвом Юди Голоніта, яким він захоплюється: „Правдивий вождь!... / Він, умираючи, до помсти кликав... / Я заповіт той перейняв і з ним / Блукаю ось світами і шукаю / Того, кому його я передам..." ${ }^{\prime \prime}$. Драма буття Юди ускладнюється й особистісними колізіями, адже він палко закоханий у Марію Магдалину, колишню блудницю, яку врятував Христос від одержимості бісами. Подібна версія - закоханість Юди в Марію Магдалину - розгортається і в поезії А. Кримського Iуда Скаріотський, підзаголовок якої (історія озлобленої душі) виявляє прагнення автора зануритися у внутрішній світ зрадника, зрозуміти мотиви, що штовхнули Юду до такого ганебного вчинку.

Для кращого осягнення авторської концепції євангельського зрадника слід звернутися до епістолярію С. Черкасенка. І. Котяш, дослідниця листування митця, справедливо зауважує, що

процес формування основ ідейного світогляду, його морально-ціннісних підвалин розпочинається ще в дитячі роки С. Черкасенка і першим поштовхом до цього ста-

\footnotetext{
${ }^{9}$ М. Б а х т и н, Эстетика словесного творчества, Москва 1979, с. 407-408.

${ }^{10}$ С. Ч е р к а с е н к о, Ціна крові, [в:] його ж, Твори..., зазнач. джерело, т. 1, с. 760.
} 
ли, за свідченням письменника, його роздуми, навіяні образами 3 текстів Святого Письма... ${ }^{11}$.

Як бачимо, біблійний світ ще змалечку заполонив уяву автора. Вивчаючи Закон Божий в учительській семінарії, молодий Черкасенко замислювався над питаннями віри. В одному з листів до Л. Білецького він писав про конфлікт з учителем на грунті канонічного трактування зради Юди:

Бесіда полягала в тім, що він почав задавати мені питання, а я мусів на них відповідати. Слово по слову, дійшло якимсь чином до апостола Юди Іскаріота та його зради. Я, скорчивши найневинніший вираз на тварі, сказав, що ніяк не можу вбагнути в себе, за що було покарано Іскаріота, коли йому заздалегідь Бог сам „предопредєліл” зрадити Христа. Чи ж винен він у тім, що зробив так? Адже на це була воля Божа, а не його ${ }^{12}$.

Цей уривок засвідчує інтерес Черкасенка до постаті Юди, зраду якого він оцінював як акт Божої волі. Образ Юди, затримавшись у глибинах авторської підсвідомості, виринув на поверхню в Ціні крові як самобутній персонаж із власною історією життя. На наш погляд, письменнику не йшлося про те, аби виправдати чи засудити зраду Юди. Гадаємо, митця цікавив цей євангельський образ як матеріал для психологічної студії над неоднозначністю, складністю людського характеру в його постійній внутрішній боротьбі між добром і злом.

Біблійний інтертекст драми не вичерпується образами Юди та Ісуса. Майже кожен персонаж твору тягне за собою цілий „шлейф” канонічних смислів (Симон-Петро, Тома, Яків, Йоан). Сліди Біблії виявляються і на рівні сюжетних запозичень. Наприклад, у пролозі до драми обігрується картина трьох спокус Христа, коли він перебував у пустелі. У ролі спокусника-сатани тут Юда, який прагне заохотити Месію до боротьби за визволення рідного народу. По-новому змальовується й біблійний епізод, в якому Христос нагодував людей двома хлібинами та п'ятьма рибинами. У драмі все це відбувається завдяки винахідливості Юди, який запропонував людям розділити свою їжу з іншими. Таким чином, біблійні образи, мотиви і сюжети утворють широкий діалогічний контекст твору, надаючи йому глибокого філософського звучання.

Інший інтертекстуальний пласт Ціни крові - це контекстуальна взаємодія 3 творчістю Лесі Українки. Дослідники неодноразово наголошували на впливі письменниці на творчу свідомість С. Черкасенка. Були й критичні оцінки твору із звинуваченнями митця в епігонстві, у невдалому творчому змаганні 3 Лесею Українкою. На нашу думку, об'єктивним, справедливим слід вважати наступне твердження О. Мишанича:

${ }^{11}$ I. К о т я ш, Епістолярій Спиридона Черкасенка як джерело формування його ідейних та художніх поглядів, [електронний ресурс:] http://dspace.tnpu.edu.ua/bitstream/123456 789/1978/1/Kotjacsh.pdf

${ }^{12}$ Там само. 
Протиставляти п’єси С. Черкасенка Еспанський кабалеро Дон Хуан і Розіта* і Ціна крові творам Лесі Українки чи іншим творам на ці теми нема підстав: в драматурга було своє бачення цих образів, у їх інтерпретації він подав ще одну версію, яка не може залишитися непоміченою ${ }^{13}$.

Підтримуючи думку ученого щодо оригінальності версії С. Черкасенка, все ж наголосимо на окремих точках дотику тексту Ціни крові і творів Лесі Українки. $€$ багато моментів, що споріднюють позиції обох письменників. Вважаємо, що слід говорити про продовження традицій Лесі Українки в порушенні проблем екзистенційного плану: свободи (національної і загальнолюдської), активного, діяльного життя на противагу пасивності, покірному підневільному існуванню. Драматичні поеми Лесі Українки на біблійну тематику, зокрема Вавилонський полон (1903), На руїнах (1904), В катакомбах (1905), утверджують думку про необхідність боротьби за волю. Ці лінії продовжив і С. Черкасенко у своєму доробку. Наприклад, у драмі Про що тирса шелестіла автор моделює образ запорізького отамана Сірка в руслі поетики символізму, виділяючи у його психіці два начала: звіряче (символом якого є Оксана) та духовне (його втілення - Килина). Хоч образ Оксани і трактується як вияв звірячого начала душі Сірка, не можна не помітити в структурі ії характеру і національну домінанту, налаштованість на активну боротьбу за волю, лицарську відвагу і мужність. Налаштованість на боротьбу за свободу підневільного народу вирізняємо і в образі Юди з Ціни крові. Інше питання, яким шляхом хочуть вибороти свободу названі персонажі. Гадаємо, що Юда, як і головний персонаж драми Лесі Українки На полі крові (1909), не зумів осягнути масштабів вчення Месії, його гуманістичного спрямування. Ісус прагнув для людей здобути Небесне Царство, він думав про вічність, а Юда мислить категоріями земного життя, хоче утвердити свою правду „тут-і-зараз”. Позиція Юди чітко виявляється у розмові з Сузанною. На докір дівчини: „Не любиш ти равві”, Юда відповідає:

Я не люблю?...

Ox, дівонько, яка ще молода ти...

Та, може ж, я палкіш за вас усіх

Йому відданий!.. Як наспіє час,

Ладен побігти буду я за ним

Останнім псом, вклонитися йому

До ніг, але не так, як ви усі...

...Й ви

Усі тоді поклонитеся йому,

*У У’єсі Еспанський кабалеро Дон Хуан і Розіта вбачали вплив Камінного господаря Лесі Українки. Можливо, С. Черкасенко й використовував як одне із джерел драму авторки, але бачення образу світового спокусника Дон Жуана відрізняється від трактувань Лесі Українки (О. К.).

${ }^{13}$ О. М и ш а н и ч, зазнач. джерело, с. 29. 


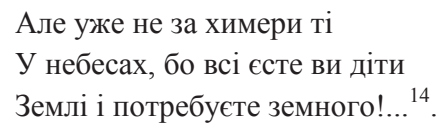

Обидва персонажі драм С. Черкасенка й Лесі Українки - прагматики, люди, що мислять земними категоріями. Вони не змогли осягнути суті Христового вчення. Якщо у Лесі Українки образ Юди проектується на рівень особистісного, загальнолюдського, то в Черкасенка мотивації зради учня Месії розширюються й проблематикою національно-визвольної боротьби.

Пролог драми Ціна крові також викликає асоціації з драматичною поемою Лесі Українки Одержима (1901). Діалог Юди й Ісуса за тональністю нагадує розмову одержимої духом жінки Міріам з Месією.Той же „антураж” - „глуха гірська пустельна місцевість”, і так само зображується самотній Христос, який сидить в задумі. Й аналогічно у двох ситуаціях, змодельованих авторами, персонажі не розуміють основ і мети Ісусового приходу на землю. Міріам прагне земного кохання, яке Христос не може їй подарувати, а Юда хоче закликати Вчителя до боротьби з римськими поневолювачами. I Міріам, і Юда занурені в ситуацію „тут-буття”. Юда не сприймає мудрих слів Ісуса: „Хто вільний духом, той не раб. І я / Зроблю їх духом вільними навіки"15.

Окреслення проблеми взаємодії творчих світів Лесі Українки та С. Черкасенка було б неповним без врахування жанрової природи їх п’єс. У доробку письменниці активно розвинувся жанр драматичної поеми філософського змісту. Поглиблений філософізм характерний і для драматичних творів Лесі Українки, в яких опрацьовуються біблійні мотиви і сюжети. Можна погодитися з твердженням I. Бетко, що „органічність біблійної тематики у царині філософської поеми засвідчує тяжіння жанру до широкої культурологічної

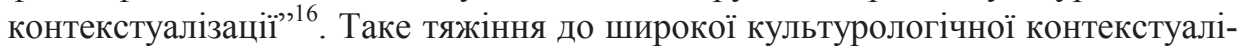
зації виявляється і в доробку Черкасенка, який зумів талановито застосувати таке складне жанрове утворення, як філософська драматична поема, для реалізації своїх художніх задумів. Ціна крові, на наш погляд, засвідчує плідне продовження традицій Лесі Українки в оновленні жанрових форм в українському письменстві.

Безперечно, проблема творчої взаємодії художніх світів Лесі Українки й Черкасенка потребує глибших досліджень. Стосовно драми Ціна крові, то слід наголосити на майстерності письменника в осмисленні євангельського сюжету про зрадника Юду. Його версія доповнює парадигму українських творів, автори яких здійснили цікаві, варті уваги трактування традиційних тем, мотивів, образів у світовому письменстві.

\footnotetext{
${ }^{14}$ С. Ч е р к а с е н к о, зазнач. джерело, с. 771.

15 Там само, с. 760.

${ }^{16}$ I. Б е т к о, Біблійні сюжети і мотиви в украӥнській поезї̈ XIX-початку XX cm., Zielona Góra-Kijów 1999, c. 97.
} 
Окремий аспект інтертекстуального аналізу драми Ціна крові - це ідейнотематичний перегук із творами російського письменника Ф. Достоєвського. Черкасенко був добре обізнаний із зразками класичної російської літератури. За часи навчання в учительській семінарії він займався самоосвітою, постійно розширював обрії своїх літературних зацікавлень. А в останній рік перебування в закладі (1895) майбутній педагог вмовив батька передплачувати відомий в Росії тижневик „Нива”, в якому його видавництво „обіцяло дати «приложенієм» твори найбільшого російського письменника, Ф.М. Достоєвського..."17.

В. Антофійчук та А. Нямцу спостерегли зв'язок між драмою Ціна крові та Брати Карамазови Ф. Достоєвського. Йдеться про близькість позицій Великого Інквізитора (з поеми, яку Іван Карамазов розповідає братові Олексію) та Юди: „Що ж стосується поеми Івана Карамазова, то викладені в ній постулати безпосередньо «випереджають» погляди Юди драми Черкасенка". Зокрема, один із звинувачувальних пунктів промови Інквізитора гласить:

Ти хочеш іти в світ і йдеш з голими руками, з якоюсь обітницею свободи, якої вони, у простоті своїй і вродженім безчинстві своїм, не можуть осягнути, якого бояться вони і страхаються, - бо нічого і ніколи не було для людини і для людського суспільства нестерпнішого за свободу!... ${ }^{18}$.

Великий Інквізитор будує свої звинувачення Христу на основі логіки розгортання трьох спокус у пустелі, дорікаючи йому тим, що свобода і вільний вибір - занадто важкий тягар для людини, слабкої істоти за своєю природою. Духовним цінностям протиставляються людські інстинкти, ідеалу героя - стихія людських мас, духовній свободі - потреба щоденно заробляти на хліб насущний, ідеї краси - все жахіття реального світу. Старий Інквізитор щоразу підкреслює ідею слабкості людської натури, цим і мотивує думку про те, що люди не готові осягнути суті Христового вчення. У колі ключових ідей, висловлених Інквізитором, обертаються й думки Юди з драми Черкасенка. У розмові з Ісусом Юда каже:

$$
\begin{aligned}
& \text {..Коли син Божий ти, як люди кажуть, } \\
& \text { То оберни його у хліб - тоді } \\
& \text { Ти - цар, і світ увесь - в твоїх ногах... }{ }^{19} \text {. }
\end{aligned}
$$

Нагодувати людей хлібом (тобто задовільнити їх найменші потреби) - це перший етап у здобутті влади над людьми. Юда добре розуміє природу людського єства, тому і впевнений у справедливості своїх суджень. Повтор „дай їм хліб” увиразнює думку про перевагу земного над небесним у позиціях персонажа:

${ }^{17}$ I. К о т я ш, Епістолярій Спиридона Черкасенка..., зазнач. праця, [електронний реcypc:] http://dspace.tnpu.edu.ua/bitstream/123456789/1978/1/Kotjacsh.pdf

${ }^{18}$ В. А н т о ф і й ч у к, А. Н я м ц у, зазнач. джерело, с. 66.

${ }^{19}$ С. Ч е р к а с е н к о, зазнач. праця, с. 761. 
...Дай голодним цим ти хліб -

І всі вони посунуть за тобою...

А їх же безліч!... Дай їм хліб - тоді

Вони свої глухі відкриють слухи -

I будеш цар над світом цим! ${ }^{20}$.

На слова Ісуса про марноту земних потреб, Юда говорить ,з злобною іронією":

...краще вже було б,

Якби ти зліз на дах високий храму

I звідти кинувсь сторч: тоді б загинув

Лиш сам ти, - чуєш?... I тим легше це

Тобі вчинить, що віриш ти Письму

Святому: там же сказано, що Бог

Накаже янголам своїм тебе

Оберігать на всіх путях твоїх,

Щоб не спіткнувсь об камінь ти ногою... ${ }^{21}$.

Ісус проганяє Юду за такі слова. Але той, розрахувавши потенціал Месії як майбутнього лідера в народновизвольних змаганнях, каже: „Прощай! Ми ще зустрінемось в дорозі / I не розійдемося аж до смерті!..."22.

Діалог Юди з Ісусом в пустелі вияскравлює дві кардинально відмінні позиції: якщо Месія прагне принести людям духовне звільнення, то Юда передусім дбає про цінності земного життя. А людина за Божим задумом - це більше, ніж просто істота, яка задовільняє свої щоденні потреби. Вона має свободу вибору і наділена безсмертною душею.

У трактуванні проблеми свободи Ф.Достоєвський, на нашу думку, випереджає спостереження філософа М.Бердяєва про свободу як важкий тягар („,свобода трудна, она есть тяжелое бремя" ${ }^{23}$ ). Не кожна людина зуміє бути духовно вільною, відповідальною за кожен свій вчинок.

Аналогічні думки про свободу як важкий тягар для людини висловлюе й С. Черкасенко в драмі Ціна крові. Юда у версії письменника зрадив Iсуса, аби активізувати народ до боротьби, але все сталося інакше. Месію засудили до смерті. Юда знищений таким вчинком людей і з розчаруванням констатує:

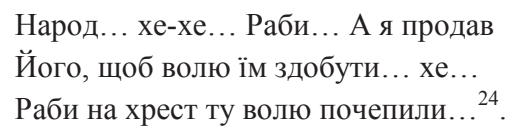


Таким чином, драматична поема С. Черкасенка Ціна крові є своєрідним текстом-,,палімпсестом”, у якому чітко вирізняються біблійний інтертекст, ідейно-тематичний зв'язок, асоціації з творами Лесі Українки, російського письменника Ф. Достоєвського. Вважаємо, що проблема інтертекстуального вивчення цієї самобутньої драми тільки окреслена, адже образ Юди став об'єктом художнього зображення у численних творах як зарубіжних, так і українських митців. Безперечно, Ціна крові становить собою цікавий матеріал для доповнення парадигми компаративних зіставлень твору українського автора з оригінальними версіями інших письменників. 